\title{
Analisa Penerapan Manajemen Waktu Pada Pelaksanaan Proyek Konstruksi Di Kota Manado
}

\author{
Yessy C.S. Pandeiroth \\ Universitas Negeri Manado \\ email: yessypandeiroth@unima.ac.id
}

\begin{abstract}
ABSTRAK
Industri jasa konstruksi di Indonesia mengalami perkembangan yang signifikan sekitar 30\% dalam kurun waktu tiga (Toyib,2017). Meskipun keterlambatan pelaksanaan proyek umumnya mengakibatkan kerugian baik dari pihak pemilik dan pihak pelaksana/kontraktor, yang memicu perdebatan tentang sumber penyebabnya dan adan implikasinya kerugian baik untuk pemilik dan kontraktor (Proboyo, 2014). Karena itu perlu penerapan manajemen waktu proyek yang tepat untuk mengatasi resiko keterlambatan waktu pelaksanaan proyek. Tujuan dari penelitian ini adalah menguji penerapan manajemen waktu pada tahap perencanaan proyek konstruksi dan untuk mengidentifikasi bagaimana menyimpan laporan kemajuan pekerjaan serta untuk mengidentifikasi proses monitoring pekerjaan pada proyek konstruksi. Data diperoleh dengan melakukan survey kuesioner kepada para pelaku jasa jasa konstruksi di kota manado.
\end{abstract}

Kata Kunci : Manajemen waktu, pengontrolan proyek, laporan kemajuan

\begin{abstract}
ABSTRACK
The construction services industry in Indonesia has experienced a significant $30 \%$ growth over the past three years (Toyib, 2017). However, the delay in the implementation of the project generally results in the loss of both the owner and the implementer, which often leads to a debate about the source of the cause and implications for the loss of both owners and contractors (Proboyo, 2014). Therefore it is necessary to implement the right project time management to overcome the risk of delay in project implementation time. Therefore, the purpose of this research is to examine the application of time management at the planning stage of the construction project and to identify how to keep the progress report of the work as well as to identify the process of monitoring the work on the construction project. Data obtained by conducting questionnaire survey to the perpetrators of construction services in Manado city
\end{abstract}

\section{Keywords : time management, project control, progress report}

\section{Pendahuluan}

Indonesia mengalami pertumbuhan signifikan sekitar $30 \%$ selama tiga tahun terakhir. Adanya pertumbuhan inti mengidikasikan bahwa kepercayaan terhadap pelaku industry konstruksi mengalami peningkatan. Hal ini dibuktikan dengan nilai kontraktor menengah ke besar sekitar $30 \%$ selama tiga tahun terakhir (Toyib, 2017)

Dalam industri konstuksi, tujuan pengendalian proyek adalah memastikan penyelesaian proyek tepat waktu, sesuai anggaran dan mencapai tujuan proyek lainnya. Ini adalah hal yang rumit yang harus dilakukan oleh meneger proyek, yang mana harus melakukan pengukuran terus-menerus terhadap kemajuan; mengevaluasi rencana dan mengambil tindakan korektif bila diperlukan (kerzner dalam Yokubu adisa alawale, 2010)

Keterlambatan pelaksanaan proyek sering dilaporkan sebagai penyebab konflik yang mempengaruhi berbagai pihak yang terlibat dalam proyek konstruksi (Solis, 2015). Umumnya berakibat pada timbulnya kerugian baik dipihak pemilik/owner maupun pihak pelaksana atau kontraktor, sehinngg 
sering hal ini mengakibatkan terjadinya perdebatan tentang sumber penyebab dan berimplikasi juga terhadap yang merugikan baik bagi pemilik maupun kontraktor, waktu dan biaya (Proboyo,2014)

Menurut wulfram Ervianto (2005), pengelolaan sebuah proyek akan barhasil baik jika fungsi manajemen dijalankan dengan efektif.

Manajemen waktu adalah salah satu kegiataan dalam proyek konstruksi berupa pencatatan dan pengendalian waktu. Dan pengelolaan waktu yang buruk, pemilihan metode pengadaan yang tidak tepat, partisipasi dari manajemen level atas, perencanaan pekerjaan konstruksi yang buruk, kurangnya menggunakan perangkat lunak, pencatatan yang buruk dan lainlain berakibat pada molornya waktu pelaksanaan, disertai dengan pembengkakan biaya, perselisihan, masalah hokum dan terabainya pelaksanaan proyek (westland,2006)

Oleh kerena itu, tujuan dari penelitan ini adalah untuk menguji penerapan manajemen waktu pada tahap perencanaan proyek konstruksi dan untuk mengidentifikasi bagaimana menyimpan laporan kemajuan pekerjaan serta untuk mengidentifikasi proses monitoring pekerjaan pada proyek konstruksi

\section{KAJIAN LITERATUR}

\section{Sistem Manajemen dan Manajemen Proyek}

Menurut H. Tarore(2001), manajemen sistem adalah proses pencatatan dan pengawasan satu sistem untuk menjamin pemenuhan dari keseluruhan sistem objektif dari sudut pandang sistem dari pekerjaan manajer memperhatikan hubungan, interaksi dan saling ketergantungan antara sub sistem yang bervariasi dengan lingkungan.. Menurut Wulfram Ervianto (2005), Manajemen Proyek adalah semua perencanaan, pelaksanaan, pengendalian dan koordinasi suatu proyek dari awal (gagasan) hingga berakhirnya proyek untuk menjamin pelaksanaan proyek secara tepat waktu, tepat biaya dan tepat mutu.

Berdasarkan definisi definisi diatas penulis memahami bahwa sistem manajemen ialah suatu proses pengelolaan pada tahapan input, tahapan proses dan tahana output pelaksanaan proyek konstruksi supaya system dapat berjalan sesuai standar yang direncanakan diawal proyek. Yang dalam penerapannya sistem ini membutuhkan manajemen proyek.

\section{Manajemen waktu}

Manajemen waktu adalah suatu proses perencanaan dan pengendalian waktu pada pelaksanaan kegiatan proyek terutama untuk meningkatkan efektivitas, efisiensi atau produktivitas.

Mackenzie mendifinisikan "manajemen waktu adalah fungsi yang dibutuhkan untuk menjaga alokasi waktu yang tepat hingga selesai. pelaksanaan proyek melalui siklus alaminya e-cycle (konsep, pengembangan konsep, pelaksanaan dan penyelesaian) mengandung arti proses perencanaan waktu, estimasi waktu, penjadwalan waktu, dan pengendalian jadwal. Manajemen proyek yang efektif adalah sangat penting untuk proyek konstruks

Manajemen waktu proyek memasukkan semua proses yang dibutuhkan dalam upaya untuk memastikan waktu penyelesaian proyek (PMI 2000). Ada lima proses utama dalam manajemen waktu proyek :

a. Pendefinisian Aktivitas 
Merupakan proses identifikasi semua aktivitas spesifik yang harus dilakukan dalam rangka mencapai seluruh tujuan dan sasaran proyek (project deliveriables). Dalam proses ini dihasilkan pengelompokkan semua aktivitas yang menjadi ruang lingkup proyek dari level tertinggi hingga level yang terkecil atau disebut Work Breakdown Structure (WBS).

\section{b. Urutan Aktivitas}

Proses pengurutan aktivitas melibatkan identifikasi dan dokumentasi dari hubungan logis yang interaktif. Masing-masing aktivitas harus diurutkan secara akurat untuk mendukung pengembangan jadwal sehingga diperoleh jadwal yang realisitis. Dalam proses ini dapat digunakan alat bantu komputer untuk mempermudah pelaksanaan atau dilakukan secara manual. Teknik secara manual masih efektif untuk proyek yang berskala kecil atau di awal tahap proyek yang berskala besar, yaitu bila tidak diperlukan pendetailan yang rinci.

c. Estimasi Durasi Aktivitas

Estimasi durasi aktivitas adalah proses pengambilan informasi yang berkaitan dengan lingkup proyek dan sumber daya yang diperlukan yang kemudian dilanjutkan dengan perhitungan estimasi durasi atas semua aktivitas yang dibutuhkan dalam proyek yang digunakan sebagai input dalam pengembangan jadwal. Tingkat akurasi estimasi durasi sangat tergantung dari banyaknya informasi yang tersedia. d. Pengembangan Jadwal

Pengembangan jadwal berarti menentukan kapan suatu aktivitas dalam proyek akan dimulai dan kapan harus selesai. Pembuatan jadwal proyek merupakan proses iterasi dari proses input yang melibatkan estimasi durasi dan biaya hingga penentuan jadwal proyek.

e. Pengendalian Jadwal

Pengendalian jadwal merupakan proses untuk memastikan apakah kinerja yang dilakukan sudah sesuai dengan alokasi waktu yang sudah direncanakan. Hal yang perlu diperhatikan dalam pengendalian jadwal adalah pengaruh dari faktor-faktor yang menyebabkan perubahan jadwal, menentukan perubahan dari jadwal serat melakukan tindakan bila pelaksanaan proyek berbeda dari perencanaan awal proyek.

\section{Waktu}

Kerangka waktu dalam proyek konstruksi adalah durasi waktu pekerjaan dan dibedakan menjadi 3 aspek (Tumembow,2016):

1. Durasi waktu pelaksanaan pekerjaan (time for completion)

2. Durasi waktu masa pemeliharaan (defect liability complation

3. Durasi-durasi waktu spesifik.

Aspek-aspek manajemen waktu yaitu (Soemardi, et al., 2006):

1) Menentukan penjadwalan proyek

2) Monitoring (mengukur dan membuat laporan kemajuan proyek)

3) Membandingkan jadwal dengan kemajuan proyek 
4) Merencanakan dan menetapkan tindakan pembetulan

Memperbaharui penjadwalan proyek

Manajemen waktu proyek memerlukan alat dan kebijakan untuk menciptakan standard pengendalian dan pengukuran kinerja proyek. Kegiatan -kegiatan harus dapat menangkap dan mengelolah waktu dengan memanfaatkan bantuan alat manajemen waktu dalam proses (Mcgrow at el. 2009)

Tiga hal yang mengindikasikan bagaimana mengelolah proyek yaitu: metode kontrak, metode manajemen waktu, dan kelengkapan prinsip manajemen waktu (CIOB, 2008). Indonesia dikenal beberapa jenis kontrak yang sering digunakan yaitu: unit price, cost plus fee, lump sum, turn key, design and buil, BOT, BOO, BLT (natasa, 2015).

Kendala signifikan dalam penerapan manajemen proyek adalah kurangnya pengatahuan penggunaan alat/teknik manajemem proyek, beberapa teknik pengendalian waktu yang digunakan diantaranya: WBS, Bar chart, Linked bar chart, Network, updating time schedule, crasing time schedule, resource allocation and levelling (sawalhi, 2012).

Monitoring yang efektif, sebagai bagian yang terintegrasi dari manajemen proyek konstruksi apapun, harus didasarkan pada pengamatan sistematis dari kemajuan proyek dalam tahap perencanaan dan juga tahap realisasi (Gredka, 2014).

\section{METODE}

\section{Tahapan Penelitian}

Tahapan penelitian yang dilakukan adaah sebagai berikut
1. Survey awal

2. Studi literature

3. Pengambilan data primer dan sekunder

4. Analisis data

5. Kesimpulan saran

Diagram alir penelitian diperlihatkan pada gambar 1 .

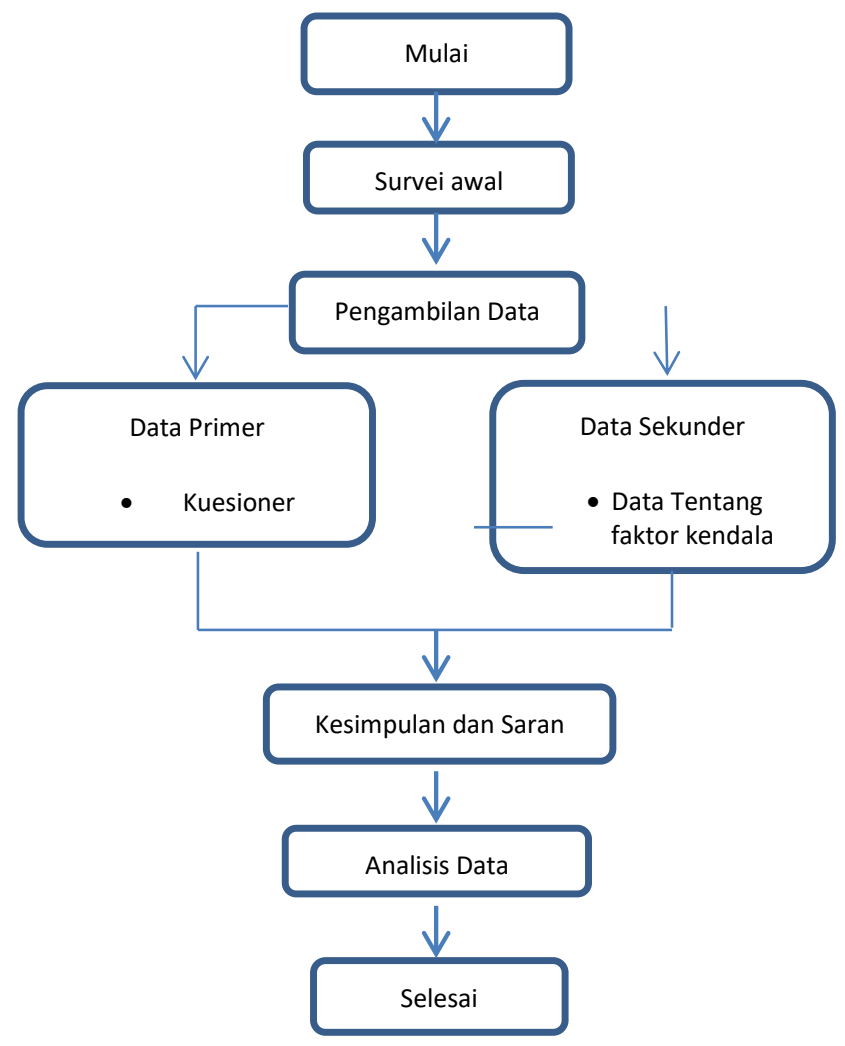

Gambar 1 : Bagan Alir Penelitian

Dengan menggunakan metode kuantitatif melalui survey kuesioner untuk mendapatkan informasi dari sampel dan menggunakan metode kualitatif untuk wawancara semiterstruktur. Alasan penggunaan wawancara selain kuesioner; untuk meningkatkan dan mempertjam ketepatan makna dari kuesioner dengan menyelidiki dan menguraikan masalah yang disorot (olawale at al, 2010). Frekuensi statistik digunakan untuk mendapatkan frekuensi dari satu set 
seleksi. Frekuensi seleksi tertinggi berarti ini adalah pilihan favorit oleh responden. Selanjutnya, menurut (Morgan et al (2007), analisis frekuensi adalah penghitungan atau hitungan berapa kali setiap skor pada satu variabel terjadi. Hasil frekuensi dapat dipilih baik dalam persentase responden $(\%)$ atau jumlah responden. Untuk pemahaman yang lebih baik dan mudah hasilnya data berubah menjadi grafik batang dan diagram lingkaran

\section{HASIL DAN PEMBAHASAN}

Penelitian dilakukan untuk menguji penerapan manajemen waktu pada kontraktor proyek konstruksi. Sebanyak 30 kuesioner ditetapkan dan didistribusikan kepada perusahaan jasa konstruksi di kota manado. Hasil dari kuesioner di analisis dan didiskusikan berdasarkan tiga tujuan penelitian.

1. Analisis data hasil kuesioner; menguji Penerapan manajemen waktu proyek kontruksi.

\section{a. Pemilihan jenis kontrak konstruksi}

Pendapat 30 responden, dapat dilihat pada tabel 1 .

Tabel 1 : Kontrak konstruksi

\begin{tabular}{lcc}
\hline Jenis Kontrak & jumlah & $\%$ \\
\hline Turn key & 2 & 6.67 \\
Tradisional & 8 & 26.67 \\
Lump-sum & 6 & 20.00 \\
Gaungan Lump- & 2 & 6.67 \\
sum dan harga & & \\
satuan & & \\
Cost plus fee & 1 & 3.33 \\
Buil-own-operate & 1 & 3.33 \\
General & - & - \\
contracting & & \\
Design and build & 3 & 10.00 \\
Construction & 1 & 3.33 \\
management & & \\
\hline
\end{tabular}

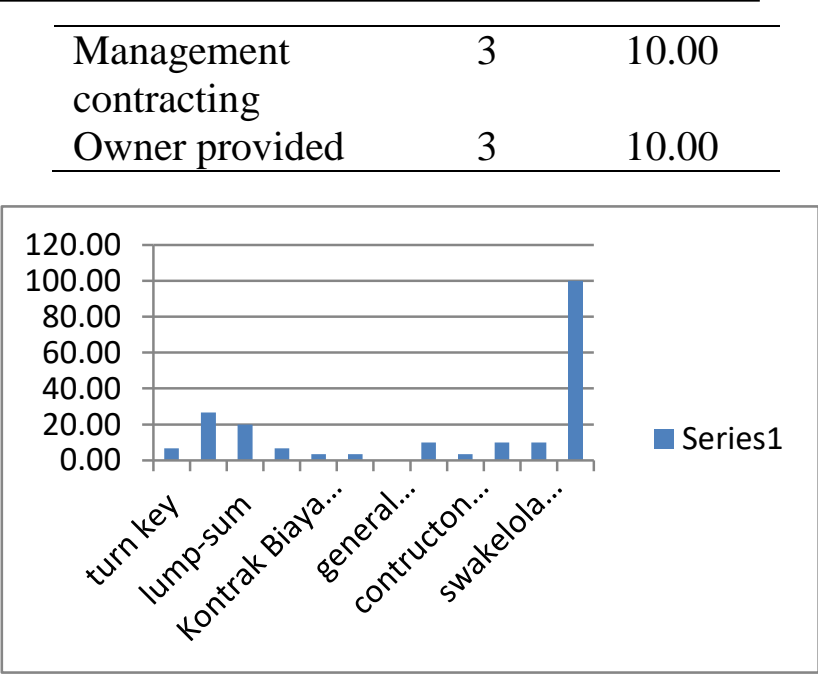

Gambar 2. Prosentase pendapat responden

Berdasarkan tabel di atas, dapat dijelaskan bahwa sebanyak $26.67 \%$ responden memilih kontrak tradisional, dikuti oleh $20 \%$ respinden memilih lump-sum kontrak dalam partisipasinya dalam manajemen waktu proyek.

\section{b. Fasilitas dan teknologi}

Pendapat dari 30 responden dapat dilihat pada tabel 2 .

Tabel 2. Fasilitas dan Teknologi

\begin{tabular}{|l|c|c|}
\hline \multicolumn{1}{|c|}{$\begin{array}{c}\text { Fasilitas dan } \\
\text { teknologi }\end{array}$} & Jumlah & $\%$ \\
\hline Meeting & 28 & 93.33 \\
\hline $\begin{array}{l}\text { Email dan voice } \\
\text { mail }\end{array}$ & 1 & 3.33 \\
\hline Video canference & 1 & 3.33 \\
\hline
\end{tabular}




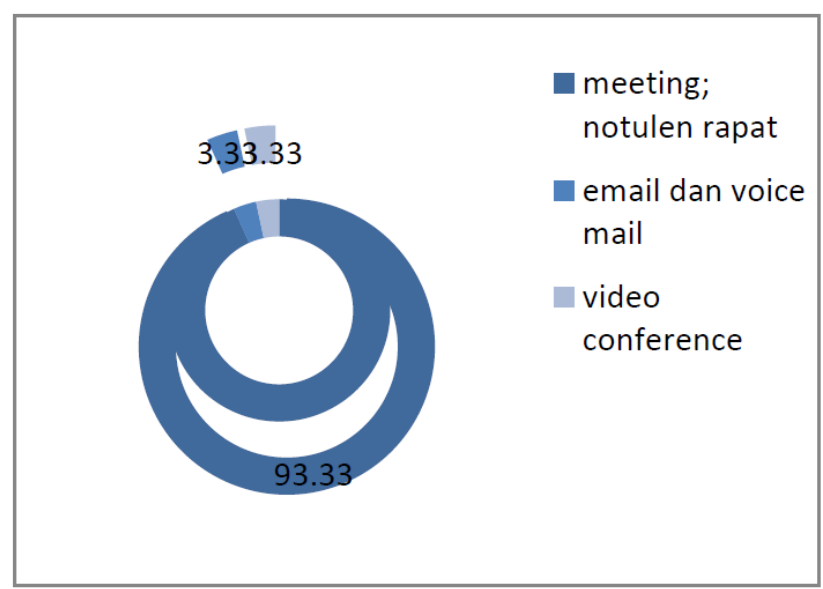

Gambar 2. Prosentase Pendapat responden

Tabel sebelumnya menjelaskan meeting dipilih responden sebagai tempat untuk bertukar infoermasi dan koordinasi dalam proyek sebanyak $93.33 \%$.

\section{c. Jenis Perangkat lunak}

Ada banyak paket perangkat lunak untuk membantu penjadwawalan dan manajemen waktu yang efektif, diantaranya; primavera project planner, Microsoft project, asta power project, Microsoft exel, project commander, deltek open plan (memon 2014). Sebanyak $74 \%$ menggunkan exel dalam penyusunan perencanaan waktu dan sekitar 5\% yang sudah menggunakan Microsoft project.

\section{d. Pihak yang terlibat dalam penyusunan draf perencanaan dan meeting manajemen}

Pendapat 30 responden dapat dilibat pada tabel 3 .

Tabel 3: Pihak yang terlibat dalam penyusunan draf perencanaan metode dan pihak yang ikut dalam rapat manajemen proyek

\begin{tabular}{|c|c|c|}
\hline Peserta & $\begin{array}{c}\text { Menyusu } \\
\mathrm{n} \\
\text { statemen } \\
\text { model } \\
\text { perencan } \\
\text { aan }\end{array}$ & $\begin{array}{c}\text { Terlibat } \\
\text { dalam } \\
\text { Rapat } \\
\text { Perencan } \\
\text { aan }\end{array}$ \\
\hline $\begin{array}{l}\text { Menejer } \\
\text { kontrak }\end{array}$ & 6.67 & 10.00 \\
\hline $\begin{array}{l}\text { Menejer } \\
\text { Proyek }\end{array}$ & 13.33 & 16.67 \\
\hline $\begin{array}{l}\text { Menejer } \\
\text { struktur }\end{array}$ & 13.33 & 3.33 \\
\hline Arsitektur & 6.67 & 10.00 \\
\hline Klien & 13.33 & 6.67 \\
\hline $\mathrm{M} / \mathrm{E}$ & 6.67 & 10.00 \\
\hline $\begin{array}{l}\text { Quntiti } \\
\text { surveyo }\end{array}$ & 6.67 & 3.33 \\
\hline $\begin{array}{l}\text { Sub } \\
\text { kontraktor }\end{array}$ & 6.67 & 13.33 \\
\hline $\begin{array}{l}\text { Sub } \\
\text { kontraktor }\end{array}$ & 6.67 & 13.33 \\
\hline $\begin{array}{l}\text { Pembuat } \\
\text { jadwal }\end{array}$ & 6.67 & 16.67 \\
\hline $\begin{array}{l}\text { Site } \\
\text { engineer }\end{array}$ & & 3.33 \\
\hline $\begin{array}{l}\text { Site } \\
\text { supervisor }\end{array}$ & & 3.33 \\
\hline $\begin{array}{l}\text { Site } \\
\text { meneger }\end{array}$ & 10.00 & 3.33 \\
\hline Supplier & 3.33 & 3.33 \\
\hline Kontraktor & 6.67 & \\
\hline
\end{tabular}

Tabel 3 di atas menunjukkan pihak meneger proyek dan pembuat jadwal memiliki prosentasi tertinggi dalam pembuatan draf stement method dan kehadiran dalam meeting.

\section{e. Mengidentifikasi durasi pada aktivitas perencanaan \\ Pernyataan responden dapat} dilihat pada gambar 4 . 


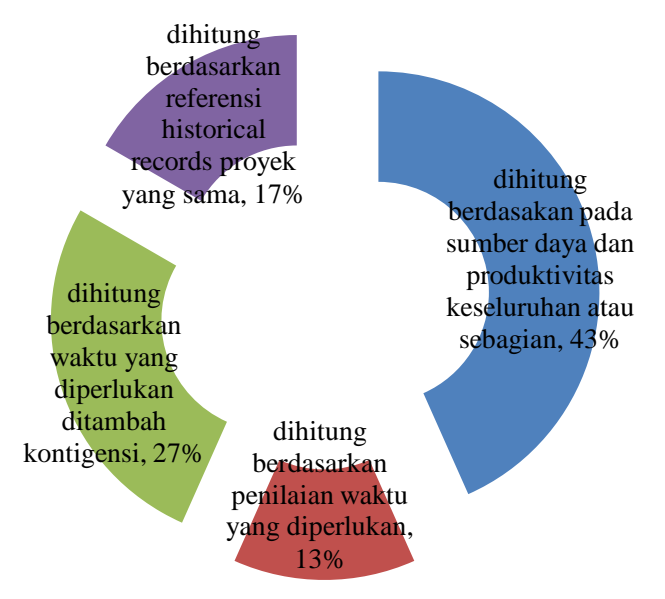

Gambar 4: Prosentase pendapat responden

Berdasarkan gambar 4 diperoleh durasi dihitung berdasarkan sumber daya dan produktivitas keselurahan atau sebagian sebanyak $44,44 \%$

\section{f. Menetapkan Ukuran kerja}

Berdasarkan gambar 5. Diperoleh bahwa responden dalam penetapan ukuran kerja memilih diskusi dengan pembuat jadwal sebesar $18.97 \%$ dan memilih diskusi dan merancang pernyataan metode sebesar $20.48 \%$

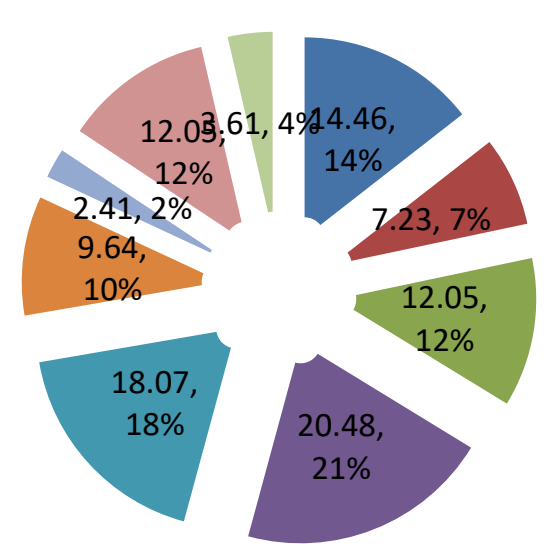

\footnotetext{
oleh merancang tentang pernyataan metode

oleh diskusi dalam meeting

- oleh diskusi +merancang dengan pembuat jadwal

- oleh diskusi dan merancang pernyataan metode

oleh diskusi dengan pembuat jadwal

- oleh pembuat jadwal berdasarkan referensi pekerjaan lainnya + pernyataan metode

oleh pembuat jadwal sendiri

oleh pembuat jadwal + referensi pekerjaan lain

- oleh merujuk pada pekerjaan lain saja.
}

\section{g. Penerapan biaya untuk kegiatan yang direncanakan}

Pernyataan 30 responden dapat dilihat pada gambar 6 


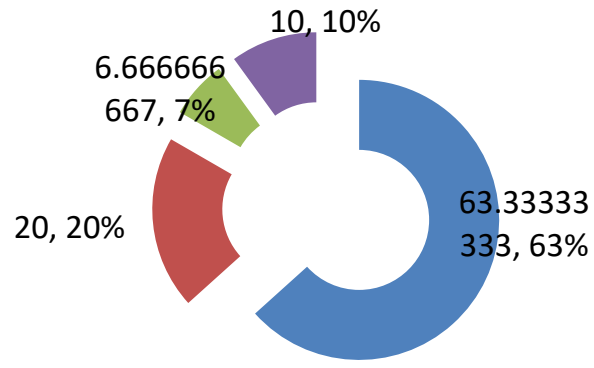

biaya dialokasikan untuk kegiatan secara keseluruhan atau sebagian dalam jadwal + kontigensi

dengan mengacu pada dokumen terpisah dari jadwal

dengan jadwal dari dokumen yang lain yang tidak berkaitan dengan jadwal yang dibuat

nilai kegiatan pada umumnya tidak diketahui

Gambar 6: pernyataan responden

Berdasarkan gambar 6 diperoleh data bahwa, responden memilih biaya dialoksikan untuk kegiatan secara keseluruhan atau sebagian jadwal ditambah kontigensi sebesar $63.33 \%$.

\section{h. Penerapan logika untuk kegiatan yang direncanakan}

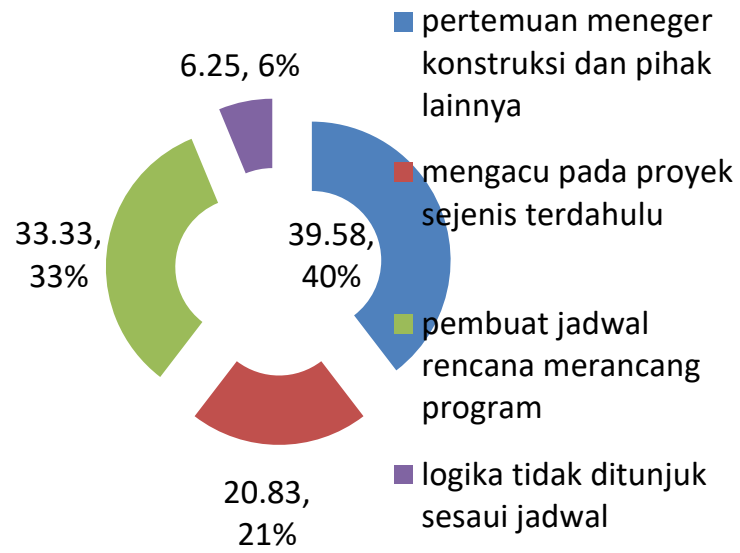

Gambar 7: pernyataan responden
Gambar 7 menunjukkan penerapan logika untuk kegiatan yang direncanakan adalah berupa pertemuan meneger konstruki dan pihak lainnya yang terkait memiliki prosentasi tertinggi sebesar $39.58 \%$.

\section{i. Kendala waktu}

Pernyataan responden terhadap kendala wakut adalah Float time digunakan untuk mengendalikan waktu kritis sebesar $40 \%$, float time biasan digunakan untuk mengidentifikasi ketergantungan $16.67 \%$, sebanyak $13.33 \%$ responden memilih tidak mengijinkan adanya float, serta responden memilih diserahkan kepada pembuat jadwal dan disesuaikan dengan jadwal proyek untuk penentuan float memiliki prosentasi yang sama yaitu $3.33 \%$

\section{j. Hubungan antar sumber daya} yang digunakan dalam penyelesaian pekerjaan dan lokasi kerja

Pernyataan responden bahwa diperlukan deskripsi pekerjaan sebesar $36.67 \%$, perlu pencatatan deskripsi tempat kerja dan penjadwalan dalam satu dokumen kendala $23.33 \%$, sebanyak $20 \%$ responden mengingikan tenaga kerja dan deskripsi kerja pada dokumen berbeda, deskripsi tempat kerja pada dokumen berbeda $13.33 \%$ dan sisanya $3.33 \%$ respond menginginkan adanya identifikasi pencatatan kerja yang sedang dikerjakan serta deskripsi tempat kerja tidak berhubungan dengan apapun.

\section{Analisa dari data kuesioner: mengidentifikasi bagaimana menyimpan laporan kemajuan pekerjaan \\ Untuk menjawab tujuan yang} kedua, analisis data kuesioner diperoleh pernyataan dari 30 responden sebagai 
berikut: laporan kemajuan pekerjaan harus mendokumentasikan rincian nama dari tipe perencanaan $26.67 \%$, selanjutnya $23.33 \%$ setuju untuk adanya laporan rincian waktu yang tersimpan di komputer dan pencatatan rekaman waktu dalam minggu. Pencatatan rincian perencanaan, pembelian dan peralatan kerja $16.67 \%$ dan sisanya sebesar $6.67 \%$ mengingikan pekerjaan dan peralatan kerja dihubungkan dengan deskripsi kerja.

\section{Analisa dari data kuesioner: mengidentifikasi bagaimana proses monitoring pekerjaan pada proyek konstruksi}

Untuk menjawab tujuan yang ketiga dianalisis pernyataan dari 30 responden tentang proses monitoring pekerjaan pada proyek konstruksi sebagai berikut: responden memfavoritkan kurva $\mathrm{s}$ dalam pengendalian dan monitoring kemajuan pekerjaan $40 \%$, dan sebanyak 20\% responden memilih untuk monitoring kemajuan diestimasi mengacu pada tahap identifikasi desain, dan sisanya 6.6\% memilih menggunakan earned value, serta $3 \%$ monitoring berdasarkan desain pekerjaan yang dilakukan.

\section{KESIMPULAN}

1. Dari hasil survey dapat disimpulkan bahwa pihak yang paling penting berpengaruh dalam perencanan manajemen waktu proyel konstruksi adalah menejer proyek, dan notulen rapat diperlukan dalam setiap meeting, durasi dihitung berdasarkan keseluruahan atau sebagian aktivitas perencanaan, penetapan ukuran kerja didasarkan atas diskusi dan merancang metode, biaya dialokasikan secara keseluruhan ditambah kontigensi, kendala waktu (float) digunakan untuk mengendalikan waktu kritis, dan diperlukan adanya deskripsi pekerjaan,

2. Pihak yang terlibat dalam proyek konstruksi mengakui perlu adanya laporan kemajuan pekerjan yang disimpan/didokumentasikan dengan baik dan mudah didapat setiap saat

3. Survey menunjukkan bahwa kurva $\mathrm{s}$ masih dipercaya untuk mengendalikan dan memonitor kemajuan pekerjaan, dan hanya sedikit yang menggunakan earned value dalam pengendalian waktu pekerjaan.

\section{DAFTAR PUSTAKA}

Aftab Hameed Memon, Ismail Abdul Rahman, Ismaaini Ismail, Noor Yasmin Zainun, (2014). "Time Management Practices in Large Construction Projects". Conference: 2014 IEEE Colloquium on Humanities Science and Engineering (CHUSER 2014). 2014 IEEE Colloquium on Humanities, Science and Engineering (CHUSER 2014).

Babu A.J.G., Nalina Suresh, (1996), "Project management with time, cost, and quality considerations", European Journal of Operational Research, Volume 88, Issue 2, 20 January 1996, Pages 320-327, ISSN 0377-2217, $\quad 10.1016 / 0377$ 2217(94)00202-9.

Budiman Proboyo,(2004), Keterlambatan waktu 
pelaksanaan proyek: klasifikasi dan peringkat dari penyebabnya". http://ced.petra.ac.id/index.php/ci v/article/viewFile/15507/15499

Chartered Industry of Building (CIOB), (2008). "Managing the Risk of Delayed Completion in the 21 st Century".

Wulfram Ervianto (2005), "Manajemen Proyek Konstruksi", Penerbit Andi.

F. D. K. Fugar and A. B. AgyakwahBaah, (2010), "Delays in building construction projects in Ghana", Australasian Journal of Construction Economics and Building, vol. 10 (1).

Gredka, (2014), "Role of monitoring a construction project with the application of the graphic visualisation method", www.ejournals.eu/Czasopismo.../ 2014/...Zeszyt2...2014/.../2902pri.

H. Tarore, (2006), "Sistem Manajemen Proyek dan Konstruksi", edisi 1, Sam Ratulangi University Press, Manado.

Mackenzie, R. A. (1990), "The time trap". New York, NY: AMACOM

Mcgraw, B.A, Leonoudakis, R. (2009), "Project Time Management: The Foundation for Effective Resource Management". Available from: http://www.rbryanpeterson.com/f iles/Project_Time_Management_ v2_2 Feb 2009-1.pdf [Assessed on $15 / 04 / 2013]$.

Nabil El Sawalhi, Adnan Enshassi, (2012), "Application of Project Time Management Tools andTechniques to the Construction Industry in the Gaza Strip", Journal Construction Economics and Building

Natasa, (2015), “Jenis-jenis kontrak dalam dunia konstruksi", https://febrinasrinatasa.wordpress .com/.../jenis-jenis-kontrak-dala.

Diakses 2 oktober 2017

Nash, S, Chinyio, E, Gameson, R and Suresh, S (2010), "The dynamism of stakeholders' power in construction projects", In: Egbu, C. (Ed) Procs 26th Annual ARCOM Conference, 6-8 September 2010, Leeds, UK, Association of Researchers in Construction Management, 471480.

PMI (2000), Project Management Institute. $A$ "Guide to the Project Management Body of Knowledge".

Rómel G. Solís-Carcaño, Gilberto A. Corona-Suárez, and Aldo J. García-Ibarra, (2015), "The Use of Project Time Management Processes and the Schedule Performance of Construction Projects in Mexico", Journal of Construction Engineering. Volume 2015 (2015), Article ID 868479,9 pages 
Soemardi, (2006), "Konsep earned value untuk pengelolaan proyek konstruksi", http://www.ftsl.itb.ac.id/kk/mana jemen_dan_rekayasa_konstruksi/

wpcontent/uploads/2007/05/makala h-earned-value.pdf

Westland, J. (2006). 'The Project Management Life Cycle: A Complete Step-by-step Methodology for Initiating Planning Executing and Closing the Project", Kogan Page Limited, London, UK.

Wiwie Yuliati Tumembow, Jermias Tjakra, Tisano Tjakrawala Arsjad (2016) “ Analisis kontrak kerja owner terhadap kontraktor (studi kasus : perumahan taman mapanget raya)". Jurnal Sipil Statik Vol.4 No.5 Mei 2016 (341-348) ISSN: 23376732Knowledge.

Y.A Olawale, and Sun M. (2010). "Cost and time control of construction projects: Inhibiting factors and mitigating measures in practice." Construction Management and Economics, Vol 28, pp 509 526. [13] PMI 2000. Project Management Institute. A Guide to the Project Management Body of Knowledge.

Yusid Toyib/ASEP BUDIMAN/PR , (2017) http://www.pikiranrakyat.com/ekonomi/2017/03/09/ industri-jasa-konstruksi-tumbuh30-dalam-3-tahun-395729. Kamis, 9 Maret 2017. Diakses tanggal 2 oktober 2017 


\section{THIS PAGE IS INTENTIONALLY LEFT BLANK}

